\title{
The Mechanism of the Oxidation of Propene to Acrolein over Antimony-Tin Mixed Oxide Catalysts
}

\author{
Takehiko Ono, ${ }^{*}$ Kurt W. Hillig II, $\dagger$ and Robert L. Kuczkowski $\dagger$ \\ *Department of Applied Chemistry, University of Osaka Prefecture, Sakai, Osaka 591, Japan; \\ and $\dagger$ Department of Chemistry, University of Michigan, Ann Arbor, Michigan 48109
}

Received September 19, 1989; revised November 21, 1989

\begin{abstract}
The oxidation of propenes such as ${ }^{13} \mathrm{CH}_{2}=\mathrm{CH}-\mathrm{CH}_{3}, \mathrm{CH}_{2}=\mathrm{CH}-\mathrm{CD}_{3}$, cis- $\mathrm{CHD}=\mathrm{CD}-\mathrm{CH}$, and $\mathrm{CH}_{2}=\mathrm{CH}-\mathrm{CH}_{3}$ was studied over $\mathrm{Sb}_{6} \mathrm{O}_{13}, \mathrm{SnO}_{2}$, and $\mathrm{Sb}-\mathrm{Sn}$ mixed oxide catalysts. The results with ${ }_{13} \mathrm{CH}_{2}=\mathrm{CH}-\mathrm{CH}_{3}$ and $\mathrm{CH}_{2}=\mathrm{CH}-\mathrm{CD}_{3}$ were consistent with a $\pi$-allyl intermediate. The isotope effect for allylic hydrogen abstraction was $1 / 0.55\left(k_{\mathrm{H}} / k_{\mathrm{D}}\right)$ over the $\mathrm{Sb}-\mathrm{Sn}$ oxide catalysts, indicating that this is the slowest step in the formation of acrolein as with other catalyst systems. The oxidation of $\mathrm{CHD}=\mathrm{CH}-\mathrm{CH}_{3}$ did not exhibit a marked isotope effect for the second hydrogen abstraction. This is inconsistent with a fast $\pi$-allyl to $\sigma$-allyl equilibration process or the irreversible $\pi$-allyl to $\sigma$-allyl conversion observed over other metal oxide catalysts. The absence of an isotope effect is similar to oxidations over rhodium. The roles of $\mathrm{Sn}$ and $\mathrm{Sb}$ ions in the oxidation are also discussed. 1990 Academic Press, Inc.
\end{abstract}

\section{INTRODUCTION}

$\mathrm{Sb}-\mathrm{Sn}$ oxide is one of the active catalysts for the partial oxidation and ammoxidation of olefins $(1,2)$. Several studies of such catalyst systems using labeled propenes have been reported. Godin et al. (3) have concluded that oxidation over a $\mathrm{Sb}-\mathrm{Sn}$ oxide catalyst proceeds via a $\pi$-allyl intermediate by using ${ }^{13} \mathrm{CH}_{2}=\mathrm{CH}-\mathrm{CH}_{3}$. Portefaix et al. (4) have reported that little or no isotope effect is observed for the abstraction of the second hydrogen over a Sb-Sn oxide catalyst using $\mathrm{CD}_{2}=\mathrm{CH}-\mathrm{CH}_{3}$. Keulks et al. (5) have found an isotope effect for the first hydrogen abstraction and little or no isotope effect for the second hydrogen abstraction over $\mathrm{U}-\mathrm{Sb}$ oxide catalysts. Similar results have been reported for the ammoxidation of propylene by Burrington et al. (6).

The oxidation of stereolabeled propene to acrolein has been studied previously by one of the authors over $\mathrm{Bi}-\mathrm{Mo}$ oxides, $\mathrm{Cu}_{2} \mathrm{O}$, $\mathrm{Rh} / \mathrm{Al}_{2} \mathrm{O}_{3}$, and unsupported $\mathrm{Rh}$ catalysts $(7$, 8 ). With $\mathrm{Bi}-\mathrm{Mo}$ oxide catalysts (7), a deuterium discrimination isotope effect in the sec- ond hydrogen abstraction was confirmed, indicating a rapid conversion between $\pi$ allyl and $\sigma$-allyl intermediates. With $\mathrm{Cu}_{2} \mathrm{O}$ catalysts $(7,8)$, an irreversible conversion of $\pi$-allyl to $\sigma$-allyl species was proposed and a deuterium isotope effect in the second hydrogen abstraction was explained through this mechanism. Another oxidation mechanism without an isotope effect in the second hydrogen abstraction was observed with rhodium catalysts (7). Such work demonstrated the usefulness of studies with a partially deuterated vinyl group $\left(\mathrm{CHD}=\mathrm{CH}-\mathrm{CH}_{3}\right)$ to distinguish between these three types of processes and prompted this study.

Many workers have studied the structure and properties of $\mathrm{Sb}-\mathrm{Sn}$ oxides $(l, 2)$. One of the authors (T.O.) has reported (9) that Sb oxide is present as noncrystalline $\mathrm{Sb}$ (III) and $\mathrm{Sb}(\mathrm{V})$ oxides dispersed on $\mathrm{SnO}_{2}$, whose surface proportions depend on the particle size of $\mathrm{SnO}_{2}$; high rates and selectivities to acrolein were obtained at a surface ratio of about $\mathrm{Sb} / \mathrm{Sn}=1 / 2$ to $1 / 3$.

In this work, labeled propenes such as $\mathrm{CH}_{2}=\mathrm{CH}-\mathrm{CD}_{3}$, cis-CHD $=\mathrm{CD}-\mathrm{CH}_{3}$, and 
${ }^{13} \mathrm{CH}_{2}=\mathrm{CH}-\mathrm{CH}_{3}$ were used to study the oxidation mechanism. The oxidations were done over $\mathrm{Sb}_{6} \mathrm{O}_{13}, \mathrm{SnO}_{2}$, and $\mathrm{Sb}-\mathrm{Sn}$ oxide catalysts. The results for these catalysts are compared with each other and with other systems such as the $\mathrm{Bi}-\mathrm{Mo}$ oxides and $\mathrm{Cu}_{2} \mathrm{O}$. The oxidation mechanism and the roles of $\mathrm{Sb}$ and $\mathrm{Sn}$ oxide ions are also discussed.

\section{METHODS}

$\mathrm{Sb}-\mathrm{Sn}$ oxide catalysts were prepared by a coprecipitation method as described in Ref. (9). Type A catalysts were prepared by coprecipitation from an aqueous solution of $\mathrm{SnCl}_{4}$ and $\mathrm{SbCl}_{5}$. Type B catalysts were prepared from $\mathrm{SnCl}_{2}$ and $\mathrm{SbCl}_{5}$. A notable difference between the $\mathrm{A}$ and $\mathrm{B}$ catalysts was in the particle size of the $\mathrm{SnO}_{2}$. $\mathrm{Sb}(30$ at. $\%)-\mathrm{Sn}$-oxide(A) and $\mathrm{Sb}(10 \%)-\mathrm{Sn}-$ oxide(B) (hereafter $\mathrm{Sb}(30) \mathrm{Sn}-\mathrm{O}$ and $\mathrm{Sb}$ (10) Sn-O) showed a maximum activity in acrolein formation as the $\mathrm{Sb}$ content was varied and were used in the present study. The preparation of $\mathrm{SnO}_{2}$ and $\mathrm{Sb}_{6} \mathrm{O}_{13}$ is also described in Ref. (9).

The catalytic oxidations of propene were carried out in a closed circulation system (ca. $1000 \mathrm{~cm}^{3}$ ). The reaction products such as acrolein, acetaldehyde, $\mathrm{CO}_{2}$, and $\mathrm{CO}$ were analyzed by gas chromatography. The reactants $\mathrm{CH}_{2}=\mathrm{CH}-\mathrm{CD}_{3} \quad(99 \%)$, cis$\mathrm{CHD}=\mathrm{CD}-\mathrm{CH}_{3} \quad(96.7 \%)$, and ${ }^{13} \mathrm{CH}_{2}=$ $\mathrm{CH}-\mathrm{CH}_{3}(99 \%)$ were obtained from MSD Canada, Ltd. $\mathrm{CH}_{2}=\mathrm{CH}-\mathrm{CH}_{3}$ and $\mathrm{O}_{2}$ were obtained from cylinders ( $99 \%$ ).

Microwave spectroscopy was used to determine the relative amounts of the isotopic acrolein products using a Hewlett-Packard $8460 \mathrm{~A}$ spectrometer. Three to five sets of rotational transitions were compared and the peak intensities were converted into molar ratios. The $4_{04}-3_{03}, 4_{14}-3_{13}$, and $4_{13}-3_{12}$ transitions were mainly used. The procedure is described elsewhere $(7,8,10)$. This was not a sufficiently large set of transitions to obtain very high precision for the samples containing three to four isotopic species, but the precision in the isotopic ratios $( \pm 5$ to $\pm 10 \%$ ) in Tables $2-6$ is sufficient to provide useful insights on the reaction processes.

\section{RESULTS AND DISCUSSION}

Catalytic activity. Typical reaction conditions and results for the oxidation of propene are given in Table 1 . The oxidation rates over $\mathrm{Sb}_{6} \mathrm{O}_{13}$ were very low, its activity being 1000 times smaller than that over $\mathrm{Sb}-\mathrm{Sn}$ oxide catalysts. The selectivity to acrolein on Sb-Sn oxide catalysts was ca. $80 \%$. The activity over $\mathrm{SnO}_{2}$ was two to three times higher than that over $\mathrm{Sb}-\mathrm{Sn}$ oxide catalysts while selectivity to acrolein was very low. The results are the same as those published previously $(9, I 1)$.

Oxidation of $\mathrm{CH}_{2}=\mathrm{CH}-\mathrm{CH}_{3}$ and $\mathrm{CH}_{2}-\mathrm{CH}-\mathrm{CD}_{3}$. An equimolar mixture of $\mathrm{CH}_{2}=\mathrm{CH}-\mathrm{CH}_{3}$ and $\mathrm{CH}_{2}=\mathrm{CH}-\mathrm{CD}_{3}$ was oxidized by the catalysts. As shown in Table 2 , the ratios of $\mathrm{CH}_{2}=\mathrm{CH}-\mathrm{CHO} /\left(\mathrm{CH}_{2}=\right.$ $\mathrm{CH}-\mathrm{CDO}+\mathrm{CD}_{2}=\mathrm{CH}-\mathrm{CHO}$ ) were about $1 / 0.6$ for $\mathrm{Sb}_{6} \mathrm{O}_{13}$ and $1 / 0.55$ for the $\mathrm{Sb}-\mathrm{Sn}$ oxide catalysts. Table 3 shows the results for the oxidation of ${ }^{13} \mathrm{CH}_{2}=\mathrm{CH}-\mathrm{CH}_{3}$ over $\mathrm{Sb}(30)-\mathrm{Sn}-\mathrm{O}$ and $\mathrm{SnO}_{2}$ catalysts. The ratio of ${ }^{13} \mathrm{CH}_{2}=\mathrm{CH}-\mathrm{CHO} / \mathrm{CH}_{2}=\mathrm{CH}-{ }^{13} \mathrm{CHO}$ for $\mathrm{Sb}(30)-\mathrm{Sn}-\mathrm{O}$ was nearly 1 . This indicates that both terminal carbon atoms are oxidized with equal probability. Thus, the ratio of $\mathrm{CH}_{2}=\mathrm{CH}-\mathrm{CHO} /\left(\mathrm{CH}_{2}=\mathrm{CH}-\mathrm{CDO}+\right.$ $\mathrm{CD}_{2}=\mathrm{CH}-\mathrm{CHO}$ ) gives the initial deuterium isotope effect for acrolein formation over $\mathrm{Sb}-\mathrm{Sn}$ oxide catalyst, i.e., the abstraction of the allylic hydrogen is the slow step in acrolein formation, the same as published previously for other oxide catalysts (Table 4). The amounts of $\mathrm{CH}_{2}=\mathrm{CH}-\mathrm{CDO}$ and $\mathrm{CD}_{2}=\mathrm{CH}-\mathrm{CHO}$ were equal (within experimental uncertainty) and indicate that the second H(D) abstraction occurs with little or no isotope effect. Portefaix also found little or no isotope effect when using $\mathrm{CD}_{2}=\mathrm{CH}-\mathrm{CH}_{3}(4)$.

With $\mathrm{SnO}_{2}$, equal amounts of ${ }^{13} \mathrm{CH}_{2}=$ $\mathrm{CH}-\mathrm{CHO}$ and $\mathrm{CH}_{2}=\mathrm{CH}-{ }^{13} \mathrm{CHO}$ were produced upon oxidation of ${ }^{13} \mathrm{CH}_{2}=$ $\mathrm{CH}-\mathrm{CH}_{3}$ as shown in Table 3. This indicates that the attack of oxygen occurs with equal 
TABLE 1

Typical Reaction Conditions and Characteristics of the Catalysts

\begin{tabular}{|c|c|c|c|c|}
\hline & $\mathrm{Sb}_{6} \mathrm{O}_{13}$ & $\mathrm{Sb}(30)-\mathrm{Sn}-\mathrm{O}^{a}$ & $\mathrm{Sb}(10)-\mathrm{Sn}-\mathrm{O}^{b}$ & $\mathrm{SnO}_{2}$ \\
\hline Surface area $\left(\mathrm{m}^{2} / \mathrm{g}\right)$ & 28 & 83 & 24 & 8.9 \\
\hline Catalyst used (g) & 1.5 & $0.036-0.05$ & 0.125 & $0.022-0.033$ \\
\hline \multicolumn{5}{|l|}{ Reactant pressure (Torr) ${ }^{c}$} \\
\hline Propene & 15 & 15 & 15 & 15 \\
\hline $\mathrm{O}_{2}$ & 30 & 30 & 30 & 15 \\
\hline Reaction temp. $\left({ }^{\circ} \mathrm{C}\right)$ & 400 & 400 & 400 & 400 \\
\hline Propene conversion (\%) & 0.8 & 20 & 10 & 11 \\
\hline $\begin{array}{l}\text { Rate, } \mathrm{C}_{3} \text { reacted } \\
\qquad\left(\mu \mathrm{mol} \mathrm{m}^{-2} \mathrm{~min}^{-1}\right)\end{array}$ & $0.002-0.003$ & $2.5-3$ & $2.6-3.5$ & $5.5-10$ \\
\hline Selectivity to acrolein (\%) & $40-60$ & 80 & 70 & $10-20$ \\
\hline
\end{tabular}

${ }^{a} \mathrm{Sb}-\mathrm{Sn}$ mixed oxide, 30 at.\% Sb, preparation A; see Methods.

${ }^{b} \mathrm{Sb}-\mathrm{Sn}$ mixed oxide, 10 at.\% Sb, preparation B; see Methods.

${ }^{c} 1$ Torr $=133.3 \mathrm{~Pa}$.

probability at both terminal carbon atoms of the $\pi$-allyl intermediate. The ratio of $\mathrm{CH}_{2}=\mathrm{CH}-\mathrm{CHO} /\left(\mathrm{CH}_{2}=\mathrm{CH}-\mathrm{CDO}+\mathrm{CD}_{2}\right.$ $=\mathrm{CH}-\mathrm{CHO}$ ) in Table 2 is ca. $1 / 0.8$, which is different from those over $\mathrm{Sb}_{6} \mathrm{O}_{13}$ and $\mathrm{Sb}$ (30)-Sn-O $(1 /(0.6-0.55))$. Deuterium substitution might be expected to retard the oxidation of deuterated species and lead to increases in their amounts relative to the normal species as observed in Table 2 .

Oxidation of cis-CHD $=\mathrm{CD}-\mathrm{CH}_{3}$. In order to obtain more complete information on the second hydrogen abstraction step, as pointed out in the introduction, the oxidation of cis-CHD $=\mathrm{CD}-\mathrm{CH}_{3}$ was studied. The formation of the $\pi$-allyl intermediate (CHD-CD- $\mathrm{CH}_{2}$ ) should lead to four acro- lein species; see Scheme 1. Within experimental uncertainty, the results over $\mathrm{Sb}_{6} \mathrm{O}_{13}$ and the two $\mathrm{Sb}-\mathrm{Sn}-\mathrm{O}$ catalysts (Table 5) gave ratios for ACR-2-d $\mathrm{d}_{1}$ : ACR-trans-2,3$\mathrm{d}_{2}$ :ACR-cis-2,3- $\mathrm{d}_{2}$ of essentially $1: 1: 1$ while a slight excess of ACR-1,2- $\mathrm{d}_{2}$ was produced. Over $\mathrm{SnO}_{2}$ the amounts of ACR-2- $\mathrm{d}_{1}$ and ACR-1,2- $\mathrm{d}_{2}$ increased a little more.

It was shown in previous work $(7,8)$ that the ratio ACR-2- $\mathrm{d}_{1}$ : ACR-1,2- $\mathrm{d}_{2}$ : cis $-\mathrm{ACR}-$ 2,3- $\mathrm{d}_{2}:$ : trans-ACR-2,3- $\mathrm{d}_{2}$ depends on the catalyst. With a Bi-Mo oxide catalyst (7), the ratio should be approximately $0.5: 1: 1: 1$ since the terminal hydrogens and deuterium of the allyl species have equal probability of abstraction except for a deuterium isotope effect. This implies a fast equil-

TABLE 2

Relative Amounts of Acrolein Obtained from the Oxidation of $\mathrm{CH}_{2}=\mathrm{CH}-\mathrm{CH}_{3}$ and $\mathrm{CH}_{2}=\mathrm{CH}-\mathrm{CD}_{3}$ over Various Catalysts ${ }^{a}$

\begin{tabular}{lccc}
\hline & $\mathrm{CH}_{2}=\mathrm{CH}-\mathrm{CHO}$ & $\mathrm{CH}_{2}=\mathrm{CH}-\mathrm{CDO}$ & $\mathrm{CD}_{2}=\mathrm{CH}-\mathrm{CHO}$ \\
\hline $\mathrm{Sb}(30)-\mathrm{Sn}-\mathrm{O}$ & 1.00 & 0.27 & 0.28 \\
$\mathrm{Sb}(10)-\mathrm{Sn}-\mathrm{O}$ & 1.00 & 0.26 & 0.27 \\
$\mathrm{Sb}_{6} \mathrm{O}_{\mathrm{I} 3}$ & 1.00 & 0.28 & 0.30 \\
$\mathrm{SnO}_{2}$ & 1.00 & 0.42 & $0.32-0.39$ \\
\hline
\end{tabular}

${ }^{a}$ Experimental conditions are nearly the same as those in Table 1. $\mathrm{CH}_{2}=\mathrm{CH}-\mathrm{CH}_{3}$ : $\mathrm{CH}_{2}=\mathrm{CH}-\mathrm{CD}_{3}=1: 1$. 
TABLE 3

Relative Amounts of $\left[{ }^{13} \mathrm{C}\right]$-Acrolein from Oxidation of

${ }^{13} \mathrm{CH}_{2}=\mathrm{CH}-\mathrm{CH}_{3}$ over $\mathrm{SnO}_{2}$ and $\mathrm{Sb}(30)-\mathrm{Sn}-\mathrm{Oxide}^{a}$

\begin{tabular}{lcc}
\hline \multicolumn{1}{c}{ Catalyst } & ${ }^{13} \mathrm{CH}_{2}=\mathrm{CH}-\mathrm{CHO}$ & $\mathrm{CH}_{2}=\mathrm{CH}-{ }^{13} \mathrm{CHO}$ \\
\hline $\mathrm{Sb}(30)-\mathrm{Sn}-\mathrm{O}^{b}$ & 1.00 & 0.96 \\
$\mathrm{SnO}{ }_{2}^{c}$ & 1.00 & 1.00 \\
\hline
\end{tabular}

${ }^{a}$ Temperature $400^{\circ} \mathrm{C} ;{ }^{13} \mathrm{CH}_{2}=\mathrm{CH}-\mathrm{CH}_{3}, 99 \%$.

${ }^{b} P\left(\mathrm{C}_{3} \mathrm{H}_{6}\right)=14.5$ Torr and $P\left(\mathrm{O}_{2}\right)=30 \mathrm{Torr}$; propene conversion $2.4 \%$, and acrolein selectivity $71 \%$.

${ }^{c} P\left(\mathrm{C}_{3} \mathrm{H}_{6}\right)=11$ Torr and $P\left(\mathrm{O}_{2}\right)=16$ Torr, conversion $12 \%$, and selectivity $25 \%$.

ibration between $\pi$-allyl and $\sigma$-allyl species. With $\mathrm{Cu}_{2} \mathrm{O}(7,8)$, the ratio should be $0.5: 1.5: 1: 1$, which originates from an irreversible conversion of the $\pi$-allyl to a $\sigma$-allyl intermediate and a deuterium isotope effect for abstraction at the CHD end. With $\mathrm{Rh} /$ $\mathrm{Al}_{2} \mathrm{O}_{3}$ and $\mathrm{Rh}$ metal (7), little or no isotope effect is observed for the second hydrogen abstraction and the ratios should be nominally $1: 1: 1: 1$. The results over $\mathrm{Sb}_{6} \mathrm{O}_{13}$ and the $\mathrm{Sb}-\mathrm{Sn}-\mathrm{O}$ catalysts are very different from those over $\mathrm{Bi}-\mathrm{Mo}$ oxides and $\mathrm{Cu}_{2} \mathrm{O}$ but are more in line with those over Rh where no isotope effect in the second abstraction is observed. The small excess in the amount of ACR-1,2- $\mathrm{d}_{2}$ (and in ACR-2-d $\mathrm{d}_{1}$ over $\mathrm{SnO}_{2}$ ) appears significant. It may be associated with the unique deuterium substitution at the aldehyde moiety in ACR-1,2- $\mathrm{d}_{2}$ and the sensitivity of this site to an isotope effect in subsequent oxidation of acrolein to $\mathrm{CO}$ and $\mathrm{CO}_{2}$. Such a process would certainly increase the amount of ACR-1,2- $\mathrm{d}_{2}$ over poor selectivity catalysts like $\mathrm{SnO}_{2}$. Evidence for such a process was noted in Table 2 for the results over $\mathrm{SnO}_{2}$. The higher amounts of ACR-1,2- $\mathrm{d}_{2}$ might also arise from a subtle inverse isotope effect, whereby the second $\mathrm{H}$-abstraction from the CHD end of the allyl species occurs faster than that from the $\mathrm{CH}_{2}$ end. This situation is reminiscent of the inverse deuterium kinetic secondary isotope effects observed in many addition reactions to double bonds which accelerate reaction rates as deuterium substitution increases (see Ref. (15) for an illustration and further

TABLE 4

Comparison of the Primary Isotope Effect in the Oxidation of Propene to Acrolein

\begin{tabular}{|c|c|c|c|c|}
\hline Catalyst & Temp. & $\begin{array}{l}\text { Deuterated } \\
\text { propene }\end{array}$ & $\begin{array}{l}\text { Rate } \\
\text { ratio }\end{array}$ & Ref. \\
\hline $\mathrm{Bi}-\mathrm{Mo}-\mathrm{O}$ & $450^{\circ} \mathrm{C}$ & $\begin{array}{l}\mathrm{C}_{3} \mathrm{H}_{6} \\
\mathrm{C}_{3} \mathrm{D}_{6}\end{array}$ & $\begin{array}{l}1.0 \\
0.55\end{array}$ & Adams and Jennings (12) \\
\hline $\mathrm{U}-\mathrm{Sb}-\mathrm{O}$ & $400^{\circ} \mathrm{C}$ & $\begin{array}{l}\mathrm{C}_{3} \mathrm{H}_{6} \\
\mathrm{CH}_{2}=\mathrm{CD}-\mathrm{CD}_{3}\end{array}$ & $\begin{array}{l}1.0 \\
0.48\end{array}$ & Keulks et al. (5) \\
\hline Au/Support & $265^{\circ} \mathrm{C}$ & $\begin{array}{l}\mathrm{C}_{3} \mathrm{H}_{6} \\
\mathrm{CH}_{2}=\mathrm{CH}-\mathrm{CD}_{3}\end{array}$ & $\begin{array}{l}1.0 \\
0.4\end{array}$ & Cant and Hall (13) \\
\hline $\mathrm{Rh} / \mathrm{Al}_{2} \mathrm{O}_{3}$ & $180^{\circ} \mathrm{C}$ & $\begin{array}{l}\mathrm{C}_{3} \mathrm{H}_{6} \\
\mathrm{CH}_{2}=\mathrm{CH}-\mathrm{CD}_{3}\end{array}$ & $\begin{array}{l}1.0 \\
0.35\end{array}$ & Cant and Hall (14) \\
\hline $\mathrm{Sb}-\mathrm{Sn}-\mathrm{O}$ & $400^{\circ} \mathrm{C}$ & $\begin{array}{l}\mathrm{C}_{3} \overline{\mathrm{H}}_{6} \\
\mathrm{CH}_{2}=\mathrm{CH}-\mathrm{CD}_{3}\end{array}$ & $\begin{array}{l}1.0 \\
0.55\end{array}$ & This work \\
\hline
\end{tabular}




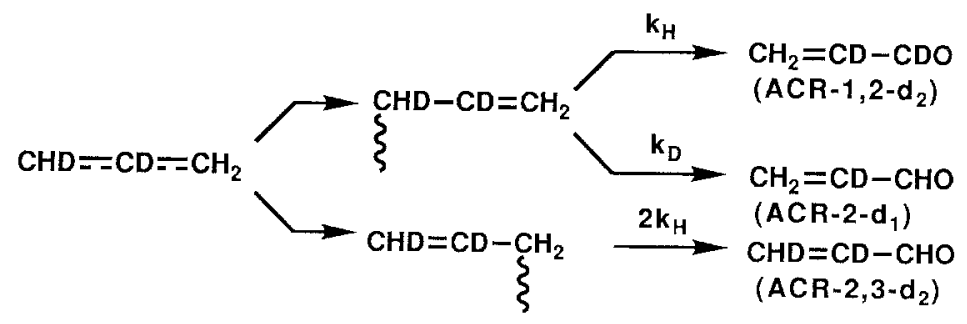

Scheme 1.

references). A speculative explanation would entail a complex interplay of zero point energy differences for reactants and transition states as the $\mathrm{CH}_{2}$ vs $\mathrm{CHD}$ ends transform to products. Another example of an inverse effect has been observed by Amenomiya and Pottie (16) who reported that the loss of $\mathrm{H}$ and $\mathrm{D}$ from deuterated ethanes in their mass spectrometric fragmentation depends on the amount of deuterium in the ethane, i.e., the loss of $\mathrm{H}$ increases with $\mathrm{D}$ substitution.

Apart from the subtle details which lead to preference for ACR-2- $\mathrm{d}_{1}$ and ACR-1,2$\mathrm{d}_{2}$, and which remain cloudy, the primary mechanistic information from the oxidation of $\mathrm{CHD}=\mathrm{CH}-\mathrm{CH}_{3}$ is that the second $\mathrm{H}$ abstraction step resembles oxidations over $\mathrm{Rh}$, where little or no isotope effect is observed, rather than over Bi-Mo oxides and copper oxide. The absence of an isotope effect is curious. It implies conversion of the $\pi$-allyl species to acrolein in a manner consistent with statistical loss of $\mathrm{H}$ and $\mathrm{D}$ uninfluenced by isotope effects. Possible interpretations in the case of $\mathrm{Rh}$ have been discussed (7). Perhaps the proximity of $\mathbf{H}$ or $\mathrm{D}$ to an active site, which occurs randomly, is an important factor. One possibility involves less symmetric surface $\sigma$-allyl intermediates as discussed in Ref. (7).

Isomerization of cis-CHD=CD-CH . Table 6 shows the results of any isomerization of propene during the oxidation reactions. With $\mathrm{Sb}_{6} \mathrm{O}_{13}$, the rate is very low, but $\mathrm{CH}_{2}=\mathrm{CD}-\mathrm{CH}_{2} \mathrm{D}$ species are formed. This indicates that the isomerization proceeds via a $\pi$-allyl mechanism. On the other hand, with $\mathrm{SnO}_{2}$ and $\mathrm{Sb}(30)-\mathrm{Sn}-\mathrm{O}$ catalysts, only trans $-\mathrm{CHD}=\mathrm{CD}-\mathrm{CH}_{3}$ is formed. On $\mathrm{SnO}_{2}$ the isomerization seems to proceed via a $\pi$ bond fission mechanism. On a $\mathrm{Sb}(30)-\mathrm{Sn}-\mathrm{O}$ catalyst, it should also take place on the $\mathrm{Sn}$ oxide sites. These facts indicate that tin ions

TABLE 5

Relative Acrolein Formation Rates in the Oxidation of cis-CHD $=\mathrm{CD}-\mathrm{CH}_{3}$ over Various Catalyst ${ }^{a}$

\begin{tabular}{|c|c|c|c|c|}
\hline & ${ }_{\substack{\left.\mathrm{ACR}-\operatorname{trans} \\
2,3-\mathrm{d}_{2}\right)}}^{\mathrm{C}=\mathrm{C}}$ & $\mathrm{H}_{\substack{\mathrm{CHO} \\
\left(\mathrm{ACR}-c i s \\
2,3-\mathrm{d}_{2}\right)}}^{\mathrm{C}=\mathrm{C}^{\mathrm{D}}}$ & 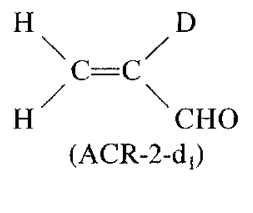 & $\underset{\left(\mathrm{ACR}-1,2-\mathrm{d}_{2}\right)}{\mathrm{C}=\mathrm{C}^{\mathrm{C}}}$ \\
\hline $\mathrm{Sb}_{6} \mathrm{O}_{13}$ & 1.00 & 0.99 & 0.97 & 1.18 \\
\hline $\mathrm{Sb}(30)-\mathrm{Sn}-\mathrm{O}$ & 1.00 & 1.00 & 1.11 & 1.28 \\
\hline $\mathrm{Sb}(10)-\mathrm{Sn}-\mathrm{O}$ & 1.00 & 1.00 & 1.17 & 1.36 \\
\hline $\mathrm{SnO}_{2}$ & 1.00 & $0.91-1.04$ & $1.24-1.40$ & $1.35-1.47$ \\
\hline
\end{tabular}

\footnotetext{
"Experimental conditions are the same as those in Table 1.
} 


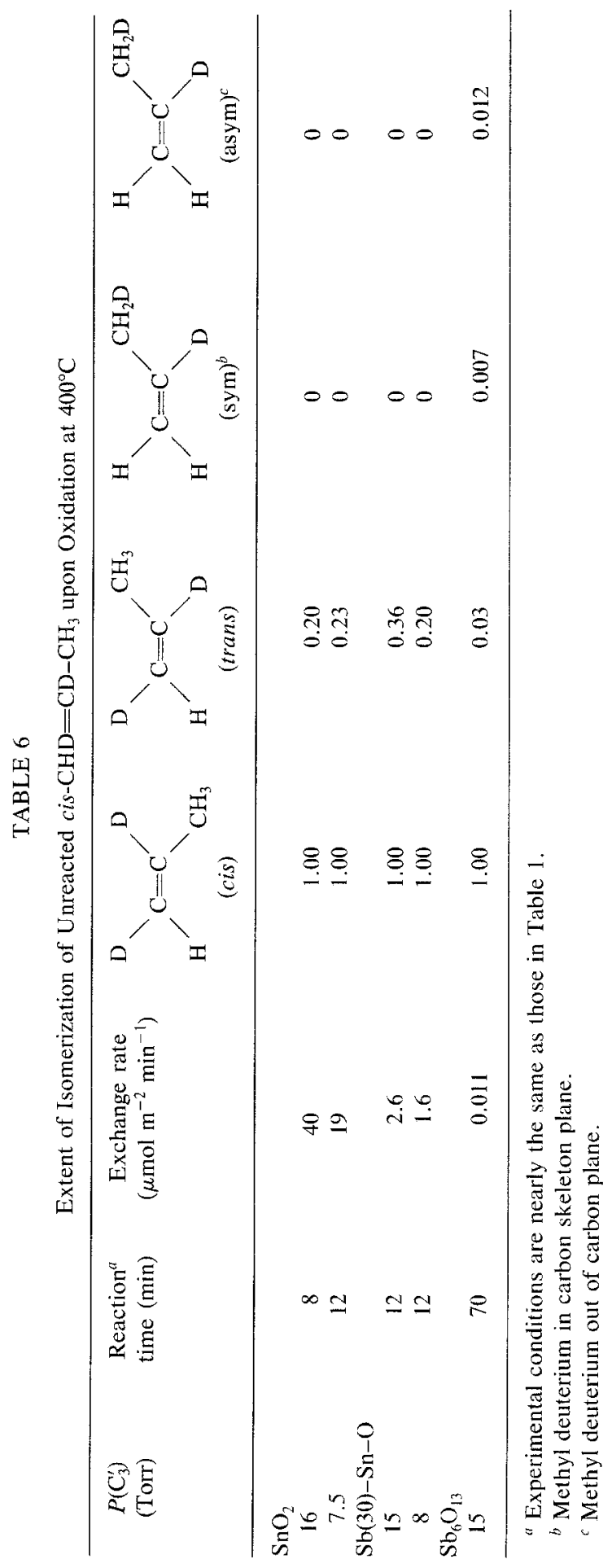


TABLE 7

Reaction Orders and Rate Constants in the Oxidation of Propene over Various Catalysts at $400^{\circ} \mathrm{C}$ (from Ref. 9)

\begin{tabular}{|c|c|c|c|c|c|}
\hline \multirow[t]{2}{*}{$\begin{array}{l}\text { Catalyst } \\
\text { (Sb at.\%) }\end{array}$} & \multicolumn{2}{|c|}{$\begin{array}{c}\text { Reaction } \\
\text { orders }\end{array}$} & \multicolumn{3}{|c|}{ Rate constants } \\
\hline & $\mathrm{C}_{3} \mathrm{H}_{6}$ & $\mathrm{O}_{2}$ & $k_{1}^{a}$ & $k_{2}^{b}$ & $k_{2} / k_{\mathrm{L}}$ \\
\hline $\mathrm{Sb}_{6} \mathrm{O}_{13}$ & 1 & 0 & 0.004 & 0.1 & 25 \\
\hline $\mathrm{Sb}(10)-\mathrm{Sn}-\mathrm{O}^{c}$ & 0.3 & 0.5 & 7.7 & 5 & 0.6 \\
\hline $\mathrm{Sb}(50)-\mathrm{Sn}-\mathrm{O}^{d}$ & 0.3 & 0.4 & 6.3 & 3.7 & 0.6 \\
\hline $\mathrm{SnO}_{2}$ & 0 & $0.4-0.5$ & $\gg k_{2}$ & $3-8$ & $\sim 0$ \\
\hline \multicolumn{6}{|c|}{$\begin{array}{l}{ }^{a, b} \text { Calculated from the equation } R=k_{1} k_{2} p\left(\mathrm{C}_{3} \mathrm{H}_{6}\right) p\left(\mathrm{O}_{2}\right)^{1 / 2} / \\
\left(k_{1} p\left(\mathrm{C}_{3} \mathrm{H}_{6}\right)+k_{2} p\left(\mathrm{O}_{2}\right)^{1 / 2}\right) ; R \text { is rate in } \mu \mathrm{mol} / \mathrm{min} \mathrm{m}^{2}\left(\mathrm{C}_{3} \mathrm{H}_{6} \text { reacted }\right) . \\
\text { Pressure ranges: } P\left(\mathrm{C}_{3} \mathrm{H}_{6}\right)=0.8-8 \mathrm{kPa} \text { and } P\left(\mathrm{O}_{2}\right)=0.8-8 \mathrm{kPa} \text {. } \\
{ }^{c} \text { Prepared by method B. See Methods. } \\
{ }^{d} \text { Prepared by method } \mathrm{A} \text {. See Methods. }\end{array}$} \\
\hline
\end{tabular}

interact more readily with propene than antimony ions.

Oxidation mechanism and catalyst composition. Grasselli et al. $(6,17,18)$ have proposed that $\mathrm{Sb}^{3+}-\mathrm{O}$ and $\mathrm{Sb}^{5+}-\mathrm{O}$ moieties are responsible for $\pi$-allyl formation and oxygen insertion, respectively. Volta et al. (19) proposed that the surface $\mathrm{Sb}^{3+}-\mathrm{Sb}^{5+}$ couples produced on $\mathrm{SnO}_{2}$ which contains $\mathrm{Sb}$ ions as a solid solution are responsible for partial oxidation. McAteer (20) suggested that acidic sites $\left(\mathrm{Sn}^{4+}\right)$ and basic sites $\left(\mathrm{Sb}^{3+}\right)$ are necessary for butene oxidation. A similar model has also been proposed by Berry (2l).

As reported previously, lattice oxygen is responsible for the propene oxidation over Sb-Sn oxide catalysts $(9,22,23)$. Ono et al. (9) have analyzed the kinetic results using a simple redox mechanism as shown in Table 7. With $\mathrm{Sb}_{6} \mathrm{O}_{13}$, the oxidation is first order in propene while with $\mathrm{Sb}-\mathrm{Sn}$ oxide catalysts the order is $0.3-0.5$ in both propene and oxygen. The kinetics are drastically changed by the addition of Sn oxides. The rate constants become ca. 1000 times larger for $k_{1}$ and 50 times for $k_{2}$ in comparison with those on $\mathrm{Sb}_{6} \mathrm{O}_{13}$. Thus, the reduction step $\left(k_{1}\right)$ is greatly promoted by the addition of Sn oxides. According to the results of Table 2 , the slow step on a $\mathrm{Sb}-\mathrm{Sn}$ oxide catalyst is also the hydrogen abstraction from $-\mathrm{CH}_{3}$. The promoter action of this step seems to originate from the presence of $\mathrm{Sn}$ ions (Scheme 2). This seems to be supported by the strong interaction between tin ions and propene as evidenced by the cis-trans isomerization reaction. As far as the reduction-oxidation mechanism is concerned, the rate for abstraction of the first hydrogen is nearly equal to that for reoxidation by gaseous oxygen on $\mathrm{Sb}-\mathrm{Sn}$ oxide catalysts.

The second hydrogen abstraction may occur on both Sb and Sn oxide ions. However, the acrolein selectivity will not become high if that step takes place solely on $\mathrm{Sn}$ ions. Furthermore, the reaction process on $\mathrm{Sb}$ (30)- $\mathrm{Sn}-\mathrm{O}$ is the same as that on $\mathrm{Sb}_{6} \mathrm{O}_{13}$ but different on $\mathrm{SnO}_{2}$, as evidenced by the oxidation of $\mathrm{CH}_{2}=\mathrm{CH}-\mathrm{CH}_{3}$ and $\mathrm{CH}_{2}$ $=\mathrm{CH}-\mathrm{CD}_{3}$ mixtures (Table 2). Thus, the conversion of the $\pi$-allyl species to acrolein seems to take place on $\mathrm{Sb}$ ions (Scheme 2). Workers at ICI (24-26) have proposed that a highly disordered $\mathrm{Sb}-\mathrm{Sn}-\mathrm{O}$ provides a suitable structure for oxidation reactions and that a favorable surface $\mathrm{Sb} /$ Sn ratio is roughly $1 / 3$. Similar results have been found also by Ono et al. (9) as described in the Introduction. A bifunctional mechanism where both Sb and Sn ions participate seems to be in operation. 


\section{Gas}<smiles>C[C@H]1C[C@@H]1C</smiles><smiles></smiles>

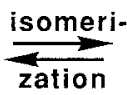

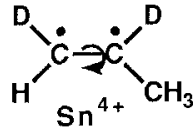

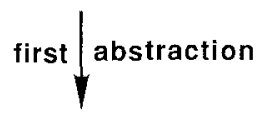<smiles>[2H]C=C([2H])[18OH]</smiles><smiles>C=C1[C@H]2C=C[C@H]1C2</smiles><smiles>[2H]C=C([2H])[C@H](C)[C@H](C)O</smiles>
second abstraction<smiles>[2H]C(=C/C=O)/C=C/C=C/C=C\C=C/C=C(\[2H])C=O</smiles>

SCHeME 2.

\section{ACKNOWLEDGMENTS}

The authors are grateful to the Rackham Graduate School at the University of Michigan for supplies and equipment funds. The microwave spectrometer was supported by a grant from the National Science Foundation, Washington, D.C.

\section{REFERENCES}

1. Berry, F. J., in "Advances in Catalysis" (D. D. Eley, H. Pines, and P. B. Weisz, Eds.), Vol. 30, p. 97. Academic Press, San Diego, 1981.

2. Centi, G., and Trifiro, F., Catal. Rev. 28, 165 (1986).

3. Godin, G. W., McCain, C. C., and Porter, E. A., in "Proceedings, 4th International Congress on $\mathrm{Ca}$ talysis, Moscow, 1968' (B. A. Kazansky, Ed.), Vol. 1, p. 271. Akad. Kiado, Budapest, 1971.

4. Portefaix, J. L., Figueras, F., and Forissier, M., $J$. Catal. 63, 307 (1980).

5. Keulks, G. W., Yu, Z., and Krenzke, L. D., J. Catal. 84, 38 (1983).

6. Burrington, J. D., Kartisek, C. T., and Grasselli, R. K., J. Catal. 87, 363 (1984).
7. Imachi, M., Kuczkowski, R. L., Groves, J. T., and Cant, N. W., J. Catal. 82, 355 (1983).

8. Choi, H., Lin, J., and Kuczkowski, R. L., J. Catal. 99, 72 (1986).

9. Ono, T., Yamanaka, T., Kubokawa, Y., and Komiyama, M., J. Catal. 109, 423 (1988).

10. Imachi, M., Cant, N. W., and Kuczkowski, R. L., J. Catal. 75, 404 (1982).

11. Volta, J. C., Coudurier, G., Mutin, I., and Vedrine, J. C., J. Chem. Soc. Chem. Commun., 1044 (1982).

12. Adams, C. R., and Jennings, T. J., J. Catal. 3, 549 (1964).

13. Cant, N. W., and Hall W. K., J. Phys. Chem. 75, 2914 (1971).

14. Cant, N. W., and Hall, W. K., J. Catal. 22, 310 (1971).

15. Choe, J. I., Painter, M. K., and Kuczkowski, R. L., J. Amer. Chem. Soc. 106, 2891 (1984).

16. Amenomiya, Y., and Pottie, R. F., Canad. J. Chem. 46, 1741 (1968).

17. Grasselli, R. K., Brazdil, J. F., and Burrington, J. D., in "Proceedings, 8th International Congress on Catalysis, Berlin, 1984," Vol. V, p. 369. Dechema, Frankfurt-am-Main, 1984.

18. Teller, R. G., Brazdil, J. F., and Grasselli, R. K., J. Chem. Soc. Faraday Trans. I 81, 1693 (1985). 
19. Volta, J. C., Bussiere, P., Courdier, G., Hermann, 23. Pendleton, P., and Taylor, D., J. Chem. Soc. FaraJ. M., and Vedrine, J. C., Appl. Catal. 16, 315 (1985). day Trans I 72, 1114 (1976).

24. Pyke, D. R., Reid, R., and Tilly, R. J. D., J. Chem. Soc. Faraday Trans. 1 76, 1174 (1980).

20. McAteer, J. C., J. Chem. Soc. Faraday Trans. I 75, 2768 (1979).

21. Berry, F. J., J. Catal. 73, 349 (1982).

25. Cross, Y. M., and Pyke, D. R., J. Catal. 58, 61 (1979).

22. Christie, J. R., Taylor, D., and McCain, C. C., J. 26. Herniman, H. J., Pyke, D. R., and Reid, R., J. Chem. Soc. Faraday Trans. 1 72, 334 (1976). 